\title{
Eosinophil Response Against Classical and Emerging Respiratory Viruses: COVID-19
}

\author{
Rodrigo-Muñoz $\mathrm{JM}^{1,2}$, Sastre $\mathrm{B}^{1,2}$, Cañas $\mathrm{JA}^{1,2}$, Gil-Martínez $\mathrm{M}^{1}$, Redondo $\mathrm{N}^{1}$, del Pozo $\mathrm{V}^{1,2}$ \\ IImmunology Department, Instituto de Investigación Sanitaria (IIS) Fundación Jiménez Díaz, Madrid, Spain \\ ${ }^{2}$ CIBER de Enfermedades Respiratorias (CIBERES), Madrid, Spain
}

J Investig Allergol Clin Immunol 2021; Vol. 31(2): 94-107

doi: 10.18176/jiaci.0624

\begin{abstract}
Eosinophils were discovered more than 140 years ago. These polymorphonuclear leukocytes have a very active metabolism and contain numerous intracellular secretory granules that enable multiple effects on both health and disease status.

Classically, eosinophils have been considered important immune cells in the pathogenesis of inflammatory processes (eg, parasitic helminth infections) and allergic or pulmonary diseases (eg, asthma) and are always associated with a type 2 immune response. Furthermore, in recent years, eosinophils have been linked to the immune response by conferring host protection against fungi, bacteria, and viruses, which they recognize through several molecules, such as toll-like receptors and the retinoic acid-inducible gene 1-like receptor.

The immune protection provided by eosinophils is exerted through multiple mechanisms and properties. Eosinophils contain numerous cytoplasmatic granules that release cationic proteins, cytokines, chemokines, and other molecules, all of which contribute to their functioning. In addition to the competence of eosinophils as effector cells, their capabilities as antigen-presenting cells enable them to act in multiple situations, thus promoting diverse aspects of the immune response.

This review summarizes various aspects of eosinophil biology, with emphasis on the mechanisms used and roles played by eosinophils in host defence against viral infections and response to vaccines. The review focuses on respiratory viruses, such as the new coronavirus, SARS-CoV-2.
\end{abstract}

Key words: Eosinophils. Respiratory viruses. Immune response. Vaccines. Emerging viruses. COVID-19.

\section{Resumen}

Los eosinófilos fueron descubiertos hace más de 140 años. Este leucocito polimorfonuclear tiene un metabolismo muy activo y contiene numerosos gránulos secretores intracelulares que le permiten ejercer múltiples funciones tanto en el estado no patológico como en el de la enfermedad. Clásicamente, los eosinófilos se han considerado como importantes células inmunes en la patogénesis de procesos inflamatorios tales como infecciones parasitarias por helmintos y enfermedades alérgicas y/o pulmonares como el asma, las cuales están asociadas a una respuesta inmune tipo 2. Además, en los últimos años, los eosinófilos también han sido relacionados con la respuesta inmunológica que confiere protección al huésped contra hongos, bacterias y virus, reconociéndolos a través de varias moléculas como los receptores tipo Toll (TLR) o los receptores parecidos al gen inducible por ácido retinoico 1 (RIG-1) o RLR.

La protección inmune es ejercida a través de los múltiples mecanismos y propiedades características de estas células. Contienen numerosos gránulos citoplasmáticos que liberan proteínas catiónicas, citocinas, quimiocinas y otras moléculas que contribuyen a estas funciones. Además de su competencia como células efectoras, sus capacidades como célula presentadora de antígeno les permite actuar en múltiples situaciones, promoviendo diversos aspectos de la respuesta inmune.

En esta revisión se resumen diversos aspectos de la biología de los eosinófilos y, principalmente, se repasan los mecanismos y funciones que desempeñan estas células en la defensa del huésped contra las infecciones por virus, así como la respuesta desencadenada por las vacunas víricas, focalizando la atención en los virus respiratorios como el nuevo coronavirus SARS-CoV-2.

Palabras clave: Eosinófilos. Virus respiratorios. Respuesta inmune. Vacunas. Virus emergentes. COVID-19. 


\section{Introduction}

The nature of the current COVID-19 pandemic means that considerable efforts are being made to understand this new infectious disease, specifically to unravel the underlying pathophysiological mechanisms with the aim of facilitating vaccine development. In this review, we report current knowledge on the role of eosinophils against viruses and how they are implicated in responses to vaccines. We attempt to gain an insight into how eosinophils affect and are affected by SARS-CoV-2 in patients with COVID-19.

\subsection{The Eosinophil: A Versatile Cell}

Eosinophils were first described in 1879 by Paul Ehrlich, who identified them using the aniline dye eosin [1]. They are easily differentiated from other cells, such as neutrophils and basophils, based on their characteristic morphology and bright brick-red appearance when stained with hematoxylin-eosin [2]. While the eosinophil has been the object of extensive investigation, the role of this cell in health and disease remains controversial and imprecisely defined [3].

Eosinophils are polymorphonuclear leukocytes with a bilobed nucleus that lack proliferative capacity and have a lifespan of between 8 to 12 hours before they migrate into tissues, where they can survive for several days [4]. Normally, they circulate in the blood stream at a low percentage (3\% to $6 \%$ of total granulocytes). Eosinophils have a very active metabolism and are characterized by containing numerous intracellular secretory granules in the cytoplasm [5].

Eosinophils are produced in the bone marrow from pluripotent stem cells, which differentiate towards an independent eosinophil lineage [6]. The eosinophil lineage is specified by the interplay of at least 3 classes of transcription factors, including GATA-1 (a zinc family finger member), PU.1 (an ETS family member), and members of $\mathrm{C} / \mathrm{EBP}$ (CCAAT/enhancer-binding protein family) [7]. It is important to note that 3 cytokines are particularly important in regulating eosinophil development, namely, interleukin (IL) 3, IL-5, and granulocyte-macrophage colony-stimulating factor (GM-CSF). These eosinophilopoietins likely provide permissive proliferative and differentiation signals following the instructive signals specified by the abovementioned transcription factors, with IL-5 being the most specific to the eosinophil lineage [8]. Furthermore, IL-5 is responsible for selective differentiation of eosinophils and stimulates the release of these leukocytes from bone marrow into peripheral blood [9].

The specific granules of eosinophils contain a preformed arsenal of cationic granule proteins, cytokines, chemokines, growth factors, lipid mediators, and other immunomodulatory molecules, including matrix metalloproteinases, which help eosinophils to exercise their functions [10]. The main eosinophil-derived cationic granule proteins are major basic protein, eosinophil-derived neurotoxin (EDN), eosinophil cationic protein (ECP), and eosinophil peroxidase, which play a key role in the functioning of eosinophils [11].

\subsection{Role of Eosinophils in the Immune Response Against Helminths, Fungi, Bacteria, and Viruses}

Eosinophils are multifunctional leukocytes. Historically, they have been considered to be important immune cells in the pathogenesis of numerous inflammatory processes, including parasitic helminth infections and allergic diseases, such as asthma [12-14]. In response to diverse stimuli, eosinophils are recruited from the blood stream to the inflammatory focus, where they modulate immune responses by releasing an array of cytokines and other mediators, as well as by a broad spectrum of immune mechanisms [15]

Triggering of eosinophils by engagement of receptors for cytokines, immunoglobulins, and complement can lead to the secretion of proinflammatory cytokines (IL-2, IL-4, IL-5, IL-10, IL-12, IL-13, IL-16, IL-18, transforming growth factor $[\mathrm{TGF}]-\alpha / \beta$ ), chemokines (CCL5 and eotaxin-1 [CCL11]), and lipid mediators (platelet-activating factor and leukotriene C4) [16]. Eosinophils cause tissue damage by releasing a plethora of toxic proteins and other preformed proinflammatory mediators contained in their granules through degranulation processes [17].

Eosinophils can actively promote type 2 immune responses by producing a range of immunoregulatory cytokines and other factors [18]. They can also function as nonprofessional antigen-presenting cells (APCs), processing and presenting a variety of microbial, viral, and parasitic antigens [19]. In its resting state, this cell type does not constitutively express MHC class II molecules or costimulatory molecules on the surface, although MHC class II molecules can be expressed on eosinophils upon activation by some cytokines [20].

Eosinophils have been considered end-stage cells in innate immunity, contributing to anti-parasitic immunity or allergy by their proinflammatory and destructive effects. In recent decades, many new roles have been identified for eosinophils in various pathological processes, including host protection against pathogens such as certain types of fungi, bacteria, and viruses [17]. Khan et al [21] reported high levels of type 2 interleukins in human patients with basidiobolomycosis. These findings support other results that indicate that during Basidiobolus and Conidiobolus infections, a type 2 immune response is likely activated, thus increasing blood counts of eosinophils in patients infected with these fungi [22]. Eosinophils have been studied as a marker of bacterial infections, since animal studies showed that the peripheral eosinophil count decreased with acute bacterial infection because of the accumulation of eosinophils at the inflammatory site and inhibition of egress from bone marrow $[23,24]$. Moreover, evidence is emerging that eosinophils may also have a protective role in viral infections, especially against RNA viruses such as respiratory syncytial virus (RSV) and the influenza virus $[25,26]$.

All of the abovementioned characteristics make eosinophils very versatile and functional cells, with many resources in host defence. 


\section{The Eosinophil Immune Response Against Viruses}

\subsection{Mechanisms for Viral Recognition and Clearance by Eosinophils}

Eosinophils can recognize and react against one of the smallest pathogens: viruses. All viruses have a genome inside a protein capsid, which in some cases is protected by a lipid bilayer. While the issue of whether viruses are alive or not is controversial, it is generally agreed that viruses are dependent on infecting hosts to replicate [27].

\subsubsection{Recognition of virus by eosinophil receptors}

The recognition of viral particles is made by pattern recognition receptors. These include toll-like receptors (TLRs) and retinoic acid-inducible gene 1 (RIG-1)-like receptor, which are able to identify pathogen-associated molecular patterns (PAMPs), ie, molecules that are characteristic of various pathogens. TLRs enable signalling pathways that orchestrate antigen-specific immune responses. In humans, there are 10 different TLRs, each of which can recognize distinct PAMPs [28] (Figure 1).

Eosinophils express several TLRs (eg, TLR1, TLR3, TLR4, TLR7, TLR9, and TLR10) [29]. TLR7, which recognizes single-stranded RNA (ssRNA), is one of the most important viral receptors in eosinophils. It is expressed at higher levels than in neutrophils, and signalling through the receptor increases the expression of adhesion molecules in eosinophils such as L-selectin and CD11b, induces the generation of superoxide anions, and promotes survival after activation by IFN- $\gamma[26,30,31]$.

These results were further confirmed for both TLR7 and TLR9 in eosinophils, with an increase in the secretion of IL-8, enhanced survival, chemotactic migration (CD11 bigh $/$ Lselectin $^{\text {low}}$ ), elevated activation (CD69), and secretion of EDN after stimulation of the receptors by agonists. Furthermore, when eosinophils were primed with histamine, IL-4 and IL-5 led to even higher responses for activation of TLR7 and TLR9, as seen in increased secretion of EDN and IL-8 [32]. The TLR7 signalling pathway seems to be dependent on prolyl isomerase Pin1, which is a key factor in the antiviral response

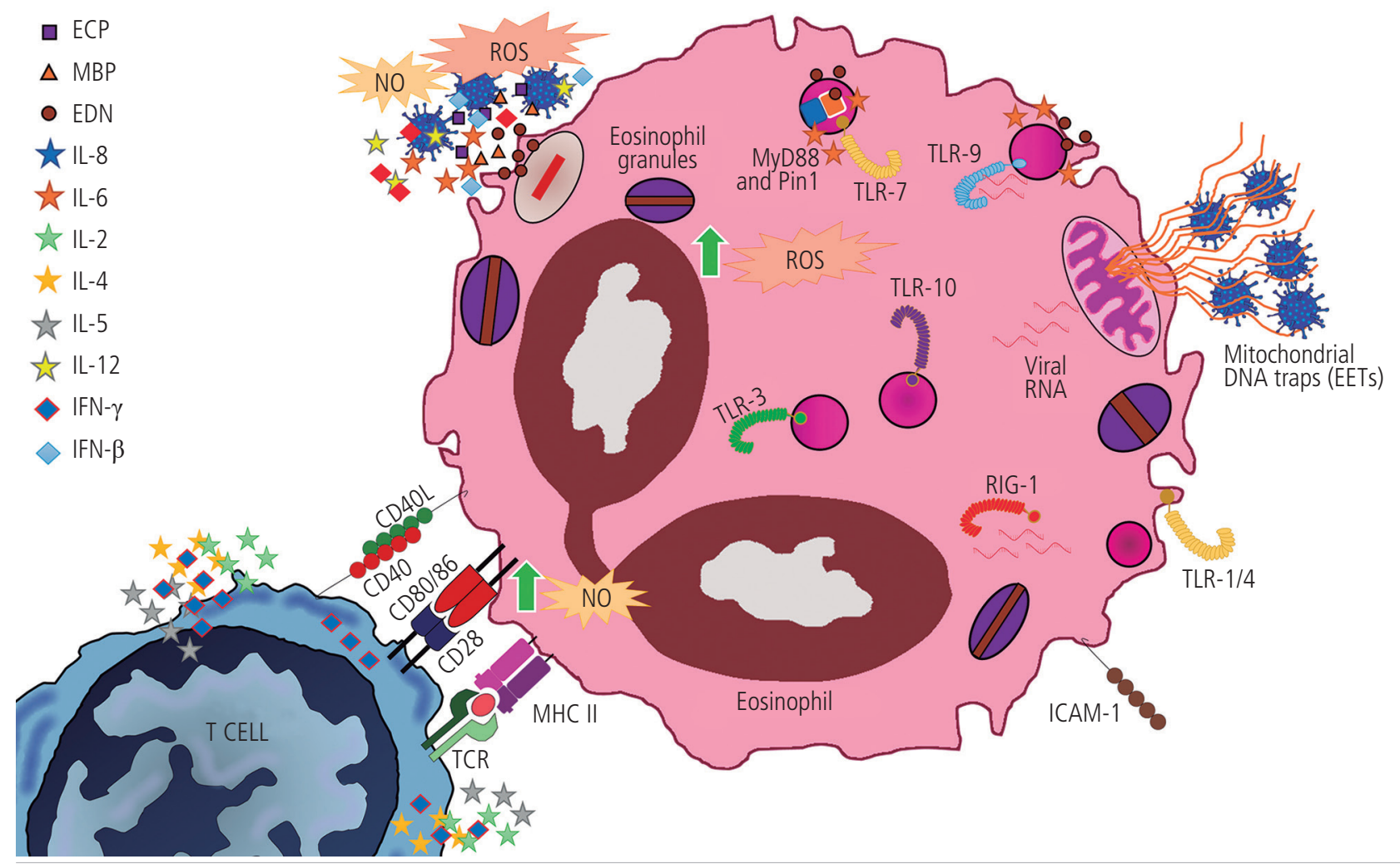

Figure 1. The eosinophilic response against viral infection comprises the following mechanisms: recognition of viral molecules (RNA) by toll-like receptors (TLRs) 3, 7, and 9, through myeloid differentiation primary response 88 (MyD88) and the prolyl isomerase Pin1, which elicit the expression of interleukin (IL) 6 and granule proteins; antigen presentation to T cells through major histocompatibility complex (MHC)-II and molecular costimulation by CD80/86 and CD40L, which causes T-cell activation and secretion of eosinophil chemoattractants, such as IL-4 and, IL-5; and finally, secretion of antiviral molecules, including eosinophil granule proteins such as eosinophil derived neurotoxin (EDN), eosinophil cationic protein (ECP), major basic protein (MBP), reactive oxygen species (ROS), and nitric oxide (NO), alongside interleukins with both antiviral and immune enhancing properties such as IL-2, IL-8, IL-12, and interferon (IFN) $\gamma / \beta$. Eosinophils are also able to secrete mitochondrial DNA traps, which are eosinophil extracellular traps (EETs) with the ability to catch and destroy virus. 
of eosinophils and in eosinophil generation in bone marrow in an IRAK4-dependent process [33].

Some of these receptors have been associated with allergic diseases. TLR3, a double-stranded RNA receptor that is decreased in eosinophils during the allergic rhinitis season and by type 2 cytokines, provides a possible link between viral infection and allergic exacerbations [34,35].

In addition, eosinophils express RIG-1 receptor, which recognizes RNA sequences with 5' triphosphorylated ends, although expression of this receptor is lower in eosinophils than in neutrophils, and agonist stimulation does not cause any effect, meaning that this receptor may be inactive [36,37].

Eosinophils are able to recognize viral particles and products of cell necrosis: they express the HMGB1 receptor, which induces eosinophil degranulation, an alternative pathway that enables a response to tissue damage by viruses such as influenza [38,39].

\subsubsection{Role of eosinophils in antigen presentation}

Eosinophils express molecules that are involved in antigen presentation as a mechanism for induction of the immune response. Treatment with GM-CSF induces eosinophilic expression of MHC-II molecules and the costimulatory proteins CD40, CD80, and CD86 and enables presentation of the antigen ovalbumin to $\mathrm{CD}^{+}$lymphocytes, which in turn induces proliferation and expression of IL-4 and IL-2. Treatment also enables presentation of parasitic antigens, thus eliciting secretion of IL-5 by lymphocytes [19,40-42]. Eosinophils express CD28, and ligation of this molecule, even independently of other signals, increases secretion of IL-2 and IFN- $\gamma$ by these cells [43].

Antigen presentation by eosinophils plays a key role in the immune response to viral infections. During the 2009 influenza pandemic, asthmatics were more likely to be hospitalized, although disease was less severe and mortality lower. Using mouse models, Samarasinghe et al [44] showed that eosinophils from the lungs of allergic asthmatic mice were activated by influenza virus, enhancing piecemeal degranulation and upregulating APC markers. Eosinophils were able to migrate to the draining lymph nodes and present viral antigens to $\mathrm{CD} 8^{+} \mathrm{T}$ cells, resulting in activation and proliferation of these cells. Another study showed that eosinophils expressing intercellular adhesion molecule (ICAM) 1 after treatment with GM-CSF were able to present antigens from rhinoviruses to $\mathrm{T}$ cells, thus promoting their proliferation and secretion of IFN- $\gamma$ [45].

Depending on the antigen type, eosinophils can induce the activation and proliferation of $\mathrm{CD} 8^{+}$and $\mathrm{CD} 4^{+} \mathrm{T}$ cells. They are able to migrate from the bronchial lumen to the paratracheal draining lymph nodes or thoracic lymph nodes to stimulate proliferation of $\mathrm{CD}^{+} \mathrm{T}$ cells by antigen presentation $[46,47]$. This migration does not seem dependent on eotaxin, but on costimulation of CD80 and CD86, with both molecules being activated by cytokines such as IL-3, and with key roles in antigen presentation by eosinophils, which induces proliferation of $\mathrm{T}$ lymphocytes in the thymus and lymph nodes $[46,48,49]$. Despite being APCs, eosinophils do not seem to be as effective as monocytes or dendritic cells; nonetheless, their action must not be disregarded [50].
The expression of specific receptors against pathogens and costimulatory molecules, together with their capacity to migrate to regional lymph nodes, shows that eosinophils are profoundly implicated in immune responses against viruses, with the ability to act as APCs [20].

\subsubsection{Antiviral action of activated eosinophils in the immune response}

Other mechanisms are very important, as they enable eosinophils to act directly against viruses. They are based on the capacity of eosinophils to synthesize molecules stored inside cytoplasmic granules and to release them, thus generating damaging effects. These molecules include ECP and EDN, which play a key role as antiparasitic and antibacterial molecules when released from granules [11] Nevertheless, they are also effective against viruses owing to their ribonuclease (RNase) activity, as both EDN and ECP have been shown to destroy the extracellular virions of RSV group B suspensions, and EDN has even been reported to have an effect against hepatitis B virus [51-56]. Indeed, eosinophils might be one of the first lines of defence against viruses. Infection of mice with pneumovirus increases eosinophil counts in the airways at day 3 ; this is associated with increased levels of eosinophil chemoattractant macrophage inflammatory protein $1-\alpha$ [57]. Eosinophils are critical in the defence against mice pneumovirus, as they are necessary for antiviral clearance and survival against lethal infection when activated in a $\mathrm{T}_{\mathrm{H}} 2$ environment [58].

Another principal characteristic of eosinophilic host defence is the capacity of the cells to synthesize and release compounds derived from oxygen or nitrogen. Through enzymes such as eosinophil peroxidase and inducible nitric oxide synthase (iNOS), eosinophils can produce both nitric oxide and bromide-derived oxidant agents, with damaging capabilities $[59,60]$. These agents, especially NO, have proven effective against viruses through a mechanism involving TLR7-myeloid differentiation primary response 88 (MyD88). Alternative eosinophilic responses against viruses comprise further activation and secretion of a massive array of molecules, such as IFN regulatory factor 7, NOS-2, IFN- $\beta$, ribonucleases (eg, EAR-1 and EAR-2), and interleukins and chemokines (eg, IL-6, IP10, CCL2, and CCL3), all of which have variable effects on viral clearance $[26,51,61,62]$.

One of the most curious lines of antiviral defence that eosinophils can achieve is mediated through extracellular traps. Yousefi et al [63] showed that eosinophils are able to catapult their mitochondrial DNA without dying. The DNA then forms extracellular structures capable of trapping and killing bacteria. A recent study performed by Silveira et al [64] found that this mechanism is also active in eosinophils from asthmatic mice exposed to RSV, thus increasing the quantity of DNA detected in bronchoalveolar lavage fluid. The results show that eosinophils also release extracellular DNA traps that have a prominent role in viral defence, similar to the traps released by neutrophils [65].

Finally, but no less important, eosinophils are able to release typical antiviral type 1 cytokines such as IFN- $\gamma$, IL-2, and IL-12 stored inside their granules in response to stimuli such as TNF- $\alpha$, IFN- $\gamma$, and IL-10 [66]. These molecules have 
proven effects in the clearance of viral infections and thus show an alternative pathway by which eosinophils fight against viruses $[67,68]$.

These mechanisms are summarized in Figure 1.

\subsection{The Interaction Between Respiratory Viruses and Eosinophils}

Eosinophils produce various molecules and present several mechanisms with potential antiviral activity, as previously mentioned. In this sense, the role of eosinophils in respiratory virus infection is very relevant owing to its connection with lung diseases characterized by an important eosinophilic inflammatory component (eg, asthma), in which respiratory viruses such as RSV or human rhinovirus (HRV) are a key element in triggering asthma exacerbations. In this sense, RSV is the main virus isolated in children aged less than 3 years during winter, whereas HRV is the most common during the rest of the year [69].

\subsubsection{Respiratory syncytial virus and vaccine studies with inactivated virus}

RSV is an enveloped, negative-sense, ssRNA virus that belongs to the Paramyxoviridae family. It is the most frequent virus causing bronchiolitis worldwide, followed by HRV [70]. After primary infection by RSV, around 30\% to $70 \%$ of infants develop bronchiolitis, and of these, $1 \%$ to $3 \%$ are hospitalized. RSV is currently a major cause of pneumonia in adults, especially in elderly patients [71-73].

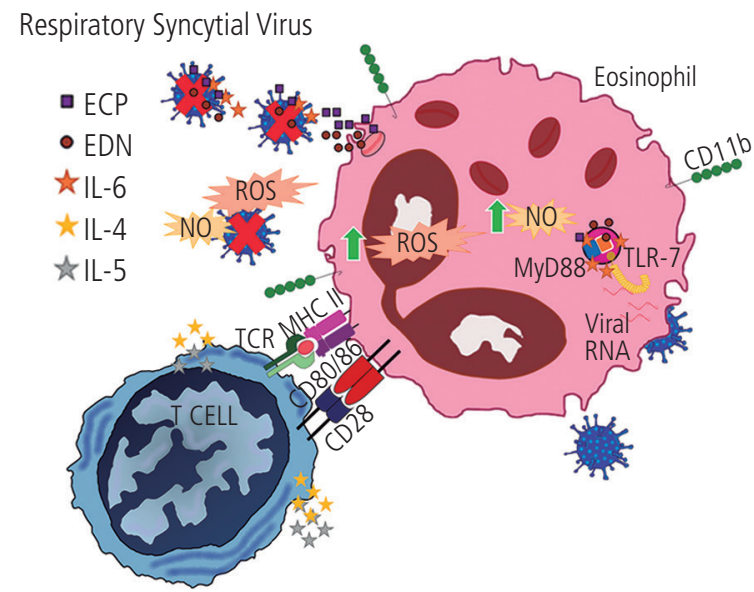

Parainfluenza Virus
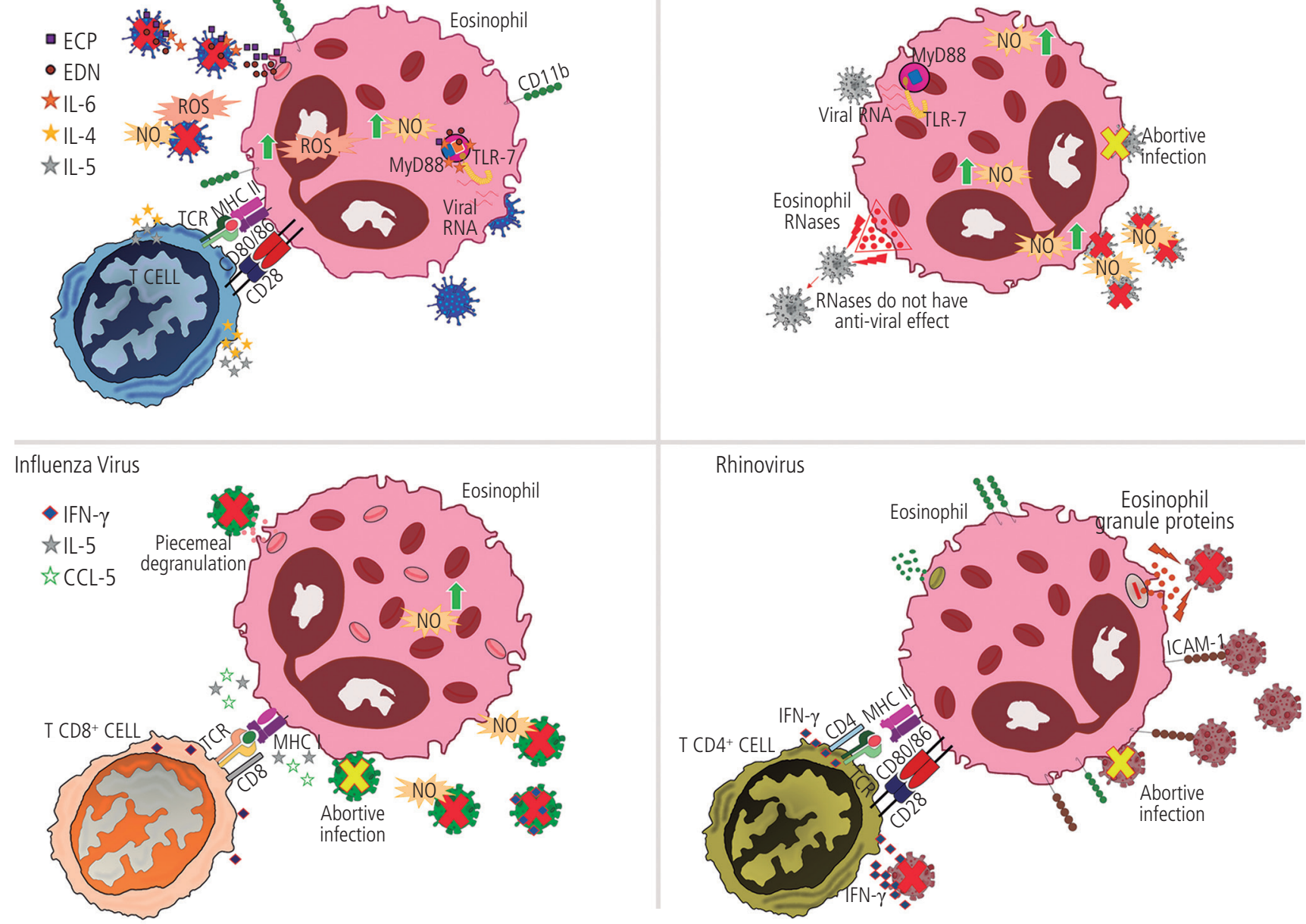

Figure 2. The specific response of eosinophils against respiratory viruses. Respiratory syncytial virus (RSV): Eosinophils infected by these viruses are able to sense viral RNA particles by Toll- like receptor (TLR) 7/Myeloid differentiation primary response 88 (MyD88) and secrete nitric oxide (NO), interleukin (IL)-6, reactive oxygen species (ROS), and eosinophil-derived neurotoxin (EDN) and upregulate CD11b. They also interact with T cells and present viral antigens by major histocompatibility complex (MHC) II binding with T-cell receptor (TCR) and costimulation by CD80/86 ligation to CD28, causing secretion of proeosinophil IL-4 and IL-5. Parainfluenza virus: Similar to RSV, eosinophilic TLR7 is activated by viral RNA, inducing secretion of NO, while eosinophil peroxidase (EPO) does not seem to be needed for viral clearance. Abortive infection is another mechanism by which viral replication is inhibited by these granulocytes. Rhinovirus: The eosinophil receptor intercellular adhesion molecule 1 (ICAM-1) is able to bind to this virus, while antigen presentation through MHC II and CD80/86 to CD4 ${ }^{+} T$ cells induces secretion of antiviral interferon IFN- $\gamma$ by these cells. Influenza virus: The main response of eosinophils attracted to the infectious focus by IL-5 and CCL-5 consists in the secretion of NO, piecemeal degranulation, and disruption of viral replication. Antigen presenting by MHC I to CD8+ cytotoxic T cells also induces these cytotoxic T cells to secrete antiviral IFN- $\gamma$. 
Recent studies have established an association between RSV infection with eosinophils and eosinophil degranulation products, which play a role in the dual capacity of eosinophils to develop a type 2 immune response and their ability to produce type 1 cytokines with pro- and anti-inflammatory properties [18,66,74,75].

When infected eosinophils are exposed to infected epithelial cells or when eosinophils are activated through TLR7 ligands, RSV triggers mechanisms such as production of IL-6, ECP, and EDN, which have antiviral activity due to their RNase capacity, or overexpression of CD11b, an activation marker in eosinophils $[30,55,62,76]$. Moreover, production of NO by iNOS due to TLR-7 has been postulated as one of the most important elements in the antiviral mechanisms by which eosinophils decrease the viral titer, with these antiviral effects probably depending on MyD88 adaptor protein-dependent signalling [26,59,77]. Furthermore, marked eosinophil recruitment to the areas affected by RSV infection is mediated through RANTES, which has been detected in the supernatant of bronchial epithelial cells infected by the virus [78] (Figure 2, upper left panel).

The first report of the connection between RSV and eosinophils was at the end of the 1960s, when Kim et al [79] performed a trial with a formalin-inactivated RSV (FI-RSV) vaccine. In this study, $80 \%$ of immunized infants were hospitalized compared with a $5 \%$ of infants in the control group, with no deaths. The authors concluded that neutralizing and protective antibodies were not produced. Furthermore, vaccinated children developed a hypersensitivity response to the viral antigens in the form of severe pneumonia and bronchoconstriction. Histological analysis of lung biopsies from 2 children who eventually died in this trial revealed relevant tissue eosinophilia and deposition of antibody-virus complexes. One or more of these characteristics have been replicated with FI-RSV in other species [80,81]. In a murine model of immunization followed by an intranasal virus challenge with FI pneumonia virus of mice (PVM), similar results were recorded for a rodent pneumovirus pathogen related to RSV, that is, pulmonary hypereosinophilia without a serum-neutralizing antibody response [82]. Consistent with the fatal outcomes in infants reported by Kim et al, Kapikian et al [83] reported that $69 \%$ of immunized infants developed pneumonia in contrast to $9 \%$ of children in the unimmunized control group. Subsequent studies have proposed that these granulocytes partly inhibit RSV and the equivalent in mice (PVM) via their granule RNases, ECP, and EDN, thus degrading viral RNA genomes $[55,56,58]$.

Multiple animal models have attempted to elucidate the mechanisms involved in the so-called vaccine-enhanced disease (VED) or immunopotentiation in order to achieve an optimal, safe, and effective antiviral vaccine. Many mouse models of FI-RSV VED have confirmed that a hallmark of this disease is pulmonary eosinophilia linked to pronounced production of type 2 cytokines, mostly IL-4, IL-5, and IL-13, with IL-4 and IL-5 playing a relevant role in immunopotentiation, since interfering with their activity markedly diminishes the severity of disease [84-87]. Therefore, contradictory results have been found related to the role of eosinophils in these murine models of VED associated with RSV, although a negative role for this kind of granulocytes is the predominant tendency.
VED associated with RSV has been analyzed in depth in murine models [88-91]. Researchers have developed various RSV models based on different vaccine formulations or infection/immunization types [88-91]. The authors analyzed and compared the immune response unleashed by FI-RSV vaccine or immunization induced through virus-like nanoparticles carrying RSV fusion proteins (F-VLP), soluble F protein, or an RSV combination vaccine composed of F-encoding plasmid DNA and virus-like particles containing RSV fusion $(F)$ and attachment $(\mathrm{G})$ glycoproteins (FFG-VLP). The models in which the viral proteins were encapsulated proved to be more efficacious than those based on the soluble F protein or FI-RSV vaccine $[88,89,91]$. These safe formulations preferentially elicited $\operatorname{IgG} 2 \mathrm{a}$ antibody and type 1 immune responses. In addition, they all showed the presence of eosinophils to be an important element of inflammatory status and linked to poorer disease progress, findings which characterize VED associated with RSV. In this sense, other authors report that $\mathrm{RSV}$-specific $\mathrm{CD} 8^{+} \mathrm{T}$ memory cells are crucial for avoidance of RSV VED, which is characterized by weight loss, bronchial hyperresponsiveness, and pulmonary eosinophilia, given that eosinophils play a harmful role $[92,93]$. Furthermore, through a murine model, Pennings et al [94] postulated that blood mRNA analysis could be used to identify an unfavorable type 2 response in VED. The authors observed an increase in expression of Ear 1/2/3/6, which are associated with eosinophils, in blood transcriptome during VRS-VED in mice that had previously received FI-RSV vaccine.

In contrast, some authors considered that eosinophils could play a dual or even protective role in RSV infection by avoiding the VED [78,95]. Su et al [78] studied the role of IL-5, eotaxin, and eosinophils in a model of vaccine-enhanced RSV disease. In the IL-5- and eotaxin-double-deficient mice, accumulation of eosinophils in the lungs was reduced in conjunction with an increase in the virus titer. The transfer of eosinophils to both deficient mice models was accompanied by rapid clearance of RSV through antiviral mediators produced by eosinophils in the form of nitric oxide [78]. Consequently, in a type 2polarized inflammatory response, migration and subsequent activation of eosinophils in the lung have both inflammatory and antiviral functions. In 2014, Percopo et al [58] showed that eosinophils promote survival in the context of a lethal infection by PVM, although they present pathophysiological features in a type 2-polarized environment. A murine model showed that immunizing eosinophil-deficient mice with a vaccine containing RSV attachment glycoprotein led to increased weight loss and clinical illness [95].

Two studies go so far as to suggest that eosinophils are not necessarily the critical immune component associated with immunopotentiation linked to administration of FI-RSV vaccine $[96,97]$. In both cases, the absence of eosinophils in the inflammatory cellular infiltrate is remarkable. All disease parameters associated with FI-RSV VED were mediated by $\mathrm{CD}^{+} \mathrm{T}$ cells, including airway obstruction, weight loss, and airway hyperresponsiveness. The depletion of $\mathrm{CD} 4^{+} \mathrm{T}$ cells led to significant amelioration of these parameters [96].

These contradictory and significantly different results indicate that, depending on the specific situation, eosinophils might induce an antiviral response against respiratory viruses. 
This response can be considered a double-edged sword, in that it simultaneously leads to an excessive immune response in an attempt to eliminate the virus and causes damage to the host [98]. More in-depth knowledge of the role and mechanisms of eosinophils in different contexts is necessary. In this sense, Flores-Torres et al [99] suggest that it would be interesting to compare the response from lung-resident and traditional eosinophils against respiratory viruses.

\subsubsection{Other respiratory viruses: human rhinovirus, influenza, and parainfluenza}

\section{Human rhinovirus}

In contrast with RSV, human rhinovirus (HRV) is a positive-sense, ssRNA member of the Picornaviridae family. As previously mentioned, HRV is the most frequently identified virus in upper respiratory tract infection and is closely linked to asthma exacerbations, mainly in childhood asthma, much in the same way as exacerbations of chronic obstructive pulmonary disease, severe bronchiolitis in infants, and lethal pneumonia in elderly and immunocompromised adults (mainly rhinovirus $\mathrm{C}$ ) $[100,101]$. Therefore, this virus is very relevant in the case of asthma, where eosinophils are key players.

The anti-HRV activity generated by eosinophils is mediated by binding of these granulocytes to HRV-16 through ICAM-1, which act as an APC inducing $\mathrm{CD}^{+}{ }^{+} \mathrm{T}$-cell proliferation and IFN- $\gamma$ production, thus increasing expression of TLR-7 on eosinophils and suggesting cooperation between eosinophils and T cells [45] (Figure 2, lower right panel).

Intriguingly, in asthmatic patients, eosinophils display a reduced capacity to bind to viruses, and HRV induces a loss of asthma control [102].

The abovementioned information is especially important in the era of new biological asthma treatments targeting eosinophils and their elimination of cytokines. Diminished CD69 expression on the surface of eosinophils in HRV-16 infection was strongly correlated with loss of control of asthma [102]. Moreover, the depletion of eosinophils as a consequence of treatment with mepolizumab, a humanized monoclonal antibody that passively eliminates eosinophils through removal of IL-5 followed by challenge with HRV-16, resulted in an enhanced viral titer, thus proving the relevance of eosinophils in viral respiratory infections [103]. In biological treatment, the extinction of eosinophils generates an important change in the innate immune response during viral infections, thus increasing the importance of macrophage function.

\section{Influenza virus}

The influenza virus, which belongs to the Orthomyxoviridae family, is an enveloped, negative-sense, segmented ssRNA virus [104]. The severity of influenza A virus (IAV) is wide, ranging from mild to lethal infection and inducing high morbidity and mortality. In fact, it is the origin of seasonal epidemics and global pandemics and is now a major cause for public health concern $[105,106]$. While eosinophils are not considered the main effector cells in the first-line antiviral immune response, as previously mentioned, epidemiological data from the 2009 H1N1 pandemic suggested that asthmatics, probably owing to pulmonary eosinophilia, are less likely to be affected by the morbidity and mortality of IAV infection [107,108].
In this context, a combined murine model of acute allergy and influenza infection showed higher eosinophil counts in the airways and rapid viral clearance, suggesting that eosinophils confer protection from IAV-induced airway damage compared with infected mice with chronic asthma and supporting the hypothesis and results of a previous study $[109,110]$. Therefore, eosinophils could be important mediators in anti-influenza immunity in specific populations of patients with type 2 polarization of the immune response.

Eosinophils develop multifaceted functions during IAV infection through piecemeal degranulation, producing several cytokines and mediators such as NO, and have the capacity to prime $\mathrm{CD}^{+} \mathrm{T}$ cells acting as APCs [44,61]. Moreover, IAV infection could be abortive in eosinophils and act a passive mechanism to limit viral expansion through these leukocytes [44].

Data from a pediatric population with acute pneumonia due to influenza virus revealed a rise in serum IL-5 levels and peripheral eosinophilia, suggesting that eosinophil recruitment may be necessary in the late stage for host defence against the influenza virus [111]. Pulmonary eosinophilia has been observed in IAV-infected mice, indicating that this eosinophil recruitment could be mediated by IL- 5 or CCL-5, which are cytokines produced during IAV infection [112,113] (Figure 2, lower left panel)

\section{Human parainfluenza virus}

Human parainfluenza virus (HPIV) is an enveloped, negative-sense, nonsegmented ssRNA member of the Paramyxoviridae family. HPIV, which is one of several viruses causing asthma exacerbations, is detected in up to $18 \%$ of adult airways during acute episodes [114].

In much the same way as for the viruses mentioned above, eosinophils seem to have an antiviral function through the TLR-MyD88 pathway [26]. In asthma, eosinophils could play an important antiviral role during infection by HPIV by reducing viral content in the lungs, an effect that is reverted when IL-5 is blocked, thus suggesting that the prior effect is originated by recruitment of eosinophils to the infected area (Figure 2, upper right panel) [115].

Drake et al [116] studied the effects of eosinophils on parainfluenza virus, both in vivo by means of an infection in mouse airways and in vitro in isolated human eosinophils. The authors propose dual functionality via proactive and passive mechanisms. Although these granulocytes generate NO that inhibits HPIV activity, eosinophilic RNases do not seem to be involved in antiviral effects. The passive mechanisms are characterized by an abortive infection that prevents HPIV from infecting eosinophils, since the propagation of infectious viral progeny fails, thus blocking viral expansion [116].

The phenomenon observed in FI-RSV vaccines has also been detected in a formalin-inactivated version of HPIV, with marked peribronchiolitis, perivasculitis, and alveolar cellular infiltration [117].

Thus, eosinophils exert beneficial effects during viral infections. However, the ability of eosinophils to respond to viruses may promote an excessive and ultimately detrimental inflammatory response in the airway of persons with asthma, leading to a generally negative perception of the role of eosinophils in respiratory diseases. 


\section{The Interaction Between Eosinophils and Coronavirus}

\subsection{Eosinophils and Their Role Against SARS-CoV-1 and in the Immune Responses in Severe Acute Respiratory Syndrome Coronavirus Vaccines}

Since the epidemic caused by the previous severe acute respiratory syndrome coronavirus (SARS-CoV) in late 2002 in China, several approaches have focused on the development of a vaccine that could protect against this human coronavirus and other potential zoonotic coronaviruses. The various vaccine candidates developed against the first SARS-CoV were based on virus-like particles, whole inactivated virus, recombinant vaccines, and/or plasmid DNA vaccines, among others $[118,119]$. However, one of the most important factors to take into account for the development of an effective and safe vaccine that protects against SARS-CoV-2, the agent causing COVID-19, and other potential coronaviruses is avoidance of undesired immunopathological effects, as occurred with the respiratory syncytial virus vaccine (see above) $[120,121]$. Indeed, a similar condition was observed during the development of vaccines for the previous SARSCoV epidemic, mostly an exacerbated immune response characterized by pathologic infiltration of eosinophils in the lungs after challenge in previously immunized animal models [119]

One of the first studies in the development of coronavirus vaccines was performed in 2006 by Deming et al [122], who used Venezuelan equine encephalitis virus replicon particles (VRP) expressing the spike (S) protein or the nucleocapsid (N) protein. In the case of the $\mathrm{S}$ protein, neutralizing antibody production was found to confer short-term protection in young mice but almost no effect in senescent animals; however, the VRP-N vaccine was not only unable to induce protection, but also caused immune abnormalities with marked eosinophil infiltration in the lungs of challenged mice [122]. Some years later, in 2011, Deming et al also studied the effect of a double-inactivated whole virus vaccine and observed the same immunopathologic effect in the lungs, with exacerbated eosinophil infiltration, concluding that this effect is caused by the presence of the $\mathrm{N}$ protein in the vaccine [123].

Another recombinant viral particle vaccine was designed by Yasui et al [124], who developed several vaccine candidates expressing all nonstructural proteins together or separately. In the cases where $\mathrm{N}$ protein was present, not only was a positive immune response with antibody production not observed, but an exacerbated immune response was also reported with marked eosinophil, neutrophil, and lymphocyte infiltration in the lungs.

Du et al [125] developed a vaccine based on the receptorbinding domain (RBD) of the SARS-Cov S protein. The authors fused this peptide to the Fc of human IgG. The RBD-Fc vaccine was very able to induce neutralizing antibodies after inoculation in BALB/c mice. In addition, no pathological damage was observed in the animals' lungs, with the neutralizing antibodies remaining for at least 6 months. While this approach seemed encouraging, higher adjuvant concentrations and more boosters are needed to induce an effective antibody response compared with other vaccines $[118,119]$.
Some years later, in 2012, Tseng et al [126] evaluated 4 SARS-CoV vaccine candidates in terms of effectiveness, safety, and immunogenic potential. The vaccines were as follows: 1) a whole virus vaccine double-inactivated with formalin and UV irradiation developed by Spruth et al [127]; 2) a whole virus vaccine inactivated with $\beta$-propiolactone; 3) a recombinant $S$ protein vaccine produced in insect cells and purified by chromatography; and 4) a virus-like-particle vaccine containing the SARS-CoV S protein and the $\mathrm{N}$ and M proteins from the mouse hepatitis coronavirus [127-130]. The conclusions of this comparative work were that the 4 vaccines studied induced a type 2 immune disease in lungs characterized by high infiltration of eosinophils in animals challenged with the virus after vaccination. However, in addition to this undesired effect, the 4 vaccines also induced neutralizing antibodies that avoided a lethal disease compared with controls [126]. An important point highlighted in this paper was the fact that the use of alum as an adjuvant could bias the immune response to a type 2 response, although the same pathologic effect was observed using vaccines without alum [126].

When trying to elucidate whether the adjuvant might bias the immune response towards a type 1 or type 2 response, Honda-Okubo et al [131] compared a range of recombinant $\mathrm{S}$ protein or whole-virus vaccines in a murine model using different types of adjuvants, including alum, $\mathrm{CpG}$, and Advax, a new delta inulin-based polysaccharide adjuvant. The authors proposed the use of inulin-based adjuvants rather than alum, since no eosinophilic immunopathology was observed in the lungs and an enhanced T-cell and humoral response may be achieved by including this adjuvant in vaccine formulations [131].

In 2014, Iwata-Yoshikawa et al [132] used a whole $\mathrm{UV}$-inactivated vaccine for immunization of $\mathrm{BALB} / \mathrm{c}$ mice and observed that the addition of a TLR agonist such as polyinosinic:polycytidylic acid, polyuridylic acid, or lipopolysaccharide during vaccination induced a high level of neutralizing antibodies against SARS-CoV but nonpathogenic eosinophil infiltration in the lungs, probably owing to a balance between the type 2 and type 1 response mediated by the stimulation by TLR and lower levels of type 2 interleukins such as IL-4 and IL-13 in the lungs.

Current knowledge will help researchers to develop an effective and safe vaccine that could protect the population against SARS-CoV-2 and, hopefully, against other potential coronaviruses affecting humans. Moreover, knowledge gained during the development of the SARS-CoV vaccine stressed the importance of not taking shortcuts and prioritizing human safety.

\subsection{Current Knowledge and Perspectives Regarding Eosinophils in COVID-19 Disease (SARS-CoV-2)}

COVID-19 is a new coronavirus disease that led the WHO to declare a Public Health Emergency of International Concern on January 30, 2020. It is responsible for one of the worst outbreaks of an infection disease to date, with over hundreds of millions of cases, and millions of deaths, all over the world [133].

Early observations in COVID-19 patients reported eosinopenia (low blood eosinophil count) in hospitalized 
patients, and, more importantly, it seems that this observation correlated with the severity of the disease or with a poor prognosis [134-139]. Accordingly, samples from lung biopsies and BAL from COVID-19 patients show aberrant and massive macrophage-based inflammation, although eosinophils were not detected, and the inflammatory profile observed in the lungs of COVID-19 patients is basically that of the $T_{H} 1$ or $\mathrm{T}_{\mathrm{H}} 17$ phenotype [140-143].

Eosinopenia is not an exclusive characteristic of COVID-19 disease. Low eosinophil count has been observed in various situations of acute inflammation such as pneumonia, but not in chronic respiratory diseases such as asthma [144-149].

Making a similar statement with respect to COVID-19 patients is controversial. Most series are studied in the same geographic region, such as China, and the number of patients is low. Lippi et al [150] reviewed the literature on eosinophils and COVID-19 and suggested that eosinopenia may not be associated with unfavourable progression of COVID-19; this conclusion is based on data from 294 patients.

By contrast, Sun et al [151] found that since eosinophil count was significantly decreased in patients with severe disease, eosinopenia was a feature of higher levels of severity. However, the limitation of the study is similar to that reported above, namely, the low number of patients studied $(n=63)$.

Importantly, eosinophil levels improved in patients before discharge, suggesting that increased eosinophil counts may indicate an improvement in a patient's clinical condition [152]. Some authors speculate that aspects of the type 2 immune response, including type 2 cytokines (eg, IL-4, IL-13) and accumulation of eosinophils, might provide potential protective effects against COVID-19 [153].

The immune mechanism of eosinopenia in COVID-19 remains unclear, although it is likely multifactorial, involving inhibition of the main steps in the eosinophil life cycle (ontogeny, rolling, adhesion, and migration), apoptosis induced by type 1 IFN during acute infection, or association with eosinophil consumption by eosinophil antiviral actions $[154,155]$. Thus, Jesenak et al [156] considered that eosinopenia could be either the sign or the symptom of host exhaustion due to clearance of COVID-19 virus.

In conclusion, eosinopenia seems to be a frequent feature in COVID-19, although studies with a larger number of patients and on the underlying mechanisms should be carried out to confirm and clarify the role of eosinophils in this emerging disease.

\section{Funding}

This study was supported by Fondo de Investigación Sanitaria - FIS and FEDER (Fondo Europeo de Desarrollo Regional) (PI15/00803, PI18/00044 and FI16/00036), CIBERES, Merck Health Foundation funds, and RTC-20176501-1 (Ministerio de Ciencia, Innovación y Universidades).

\section{Conflicts of Interest}

VdP has received honoraria (advisory board, speaker) and/ or institutional grant/research

support from AstraZeneca and GSK. The remaining authors declare that they have no conflicts of interest.

\section{References}

1. Gleich GJ, Adolphson CR. The eosinophilic leukocyte: structure and function. Adv Immunol. 1986;39:177-253.

2. Lacy P, Rosenberg HF, Walsh GM. Eosinophil overview: structure, biological properties, and key functions. Methods Mol Biol. 2014;1178:1-12.

3. O'Sullivan JA, Bochner BS. Eosinophils and eosinophilassociated diseases: An update. J Allergy Clin Immunol. 2018;141:505-17.

4. Uhm TG, Kim BS, Chung Y. Eosinophil development, regulation of eosinophil-specific genes, and role of eosinophils in the pathogenesis of asthma. Allergy Asthma Immunol Res. 2012:4:68-79.

5. Long H, Liao W, Wang L, Lu Q. A Player and Coordinator: The Versatile Roles of Eosinophils in the Immune System. Transfus Med Hemother. 2016;43:96-108.

6. Blanchard C, Rothenberg ME. Biology of the eosinophil. Adv Immunol. 2009;101:81-121.

7. McNagny K, Graf T. Making eosinophils through subtle shifts in transcription factor expression. J Exp Med. 2002;195:F43-7.

8. Ip WK, Wong CK, Wang CB, Tian YP, Lam CW. Interleukin-3, -5, and granulocyte macrophage colony-stimulating factor induce adhesion and chemotaxis of human eosinophils via p38 mitogen-activated protein kinase and nuclear factor kappaB. Immunopharmacol Immunotoxicol. 2005;27:371-93.

9. Sanderson C. Interleukin-5, eosinophils, and disease. Blood. 1992;79:3101-9.

10. Davoine F, Lacy P. Eosinophil cytokines, chemokines, and growth factors: emerging roles in immunity. Front Immunol. 2014;5:570.

11. Acharya $K R$, Ackerman SJ. Eosinophil granule proteins: form and function. J Biol Chem. 2014;289:17406-15.

12. Magalhães KG, Luna-Gomes $T$, Mesquita-Santos F, Corrêa $R$, Assunção LS, Atella $G C$, et al. Schistosomal Lipids Activate Human Eosinophils via Toll-Like Receptor 2 and PGD2Receptors: 15-LO Role in Cytokine Secretion. Front Immunol. 2019;9:3161.

13. Weller PF, Spencer LA. Functions of tissue-resident eosinophils. Nat Rev Immunol. 2017;17:746-60.

14. Busse W, Chupp G, Nagase H, Albers FC, Doyle S, Shen Q, et al. Anti-IL-5 treatments in patients with severe asthma by blood eosinophil thresholds: Indirect treatment comparison. J Allergy Clin Immunol. 2019;143:190-200.e20.

15. Rosenberg HF, Phipps S, Foster PS. Eosinophil trafficking in allergy and asthma. JAllergy Clin Immunol. 2007;119:1303-12.

16. Kita H. The eosinophil: a cytokine-producing cell? J Allergy Clin Immunol. 1996;97:889-92.

17. Kita H. Eosinophils: Multifaceted biological properties and roles in health and disease. Immunol Rev. 2011;242:16177.

18. Shamri R, Xenakis JJ, Spencer LA. Eosinophils in innate immunity: an evolving story. Cell Tissue Res. 2011;343:57-83.

19. Del Pozo $V$, de Andrés $B$, Martín $E$, Cárdaba $B$, Fernández JC, Gallardo S, et al. Eosinophil as antigen-presenting cell: activation of $T$ cell clones and $T$ cell hybridoma by eosinophils after antigen processing. Eur J Immunol. 1992;22:1919-25.

20. Shi H-Z. Eosinophils function as antigen-presenting cells. J Leukoc Biol. 2004;76:520-7. 
21. Khan ZU, Khoursheed M, Makar R, Al-Waheeb S, Al-Bader I, Al-Muzaini A, et al. Basidiobolus ranarum as an etiologic agent of gastrointestinal zygomycosis. J Clin Microbiol. 2001;39:2360-3.

22. Almoosa Z, Alsuhaibani M, AlDandan S, Alshahrani D. Pediatric gastrointestinal basidiobolomycosis mimicking malignancy. Med Mycol Case Rep. 2017;18:31-3.

23. Farris BY, Monaghan KL, Zheng W, Amend CD, Hu H, Ammer $A G$, et al. Ischemic stroke alters immune cell niche and chemokine profile in mice independent of spontaneous bacterial infection. Immun Inflamm Dis. 2019;7:326-41.

24. Choi J, Oh JY, Lee YS, Hur GY, Lee SY, Shim JJ, et al. The association between blood eosinophil percent and bacterial infection in acute exacerbation of chronic obstructive pulmonary disease. Int J COPD. 2019;14:953-9.

25. Lamichhane PP, Samarasinghe AE. The Role of Innate Leukocytes during Influenza Virus Infection. J Immunol Res. 2019;2019:8028725

26. Phipps S, En Lam C, Mahalingam S, Newhouse M, Ramirez R, Rosenberg HF, et al. Eosinophils contribute to innate antiviral immunity and promote clearance of respiratory syncytial virus. Blood. 2007:110:1578-86.

27. Mothes W, Sherer NM, Jin J, Zhong P. Virus Cell-to-Cell Transmission. J Virol. 2010;84:8360-8.

28. Kawasaki T, Kawai T. Toll-like receptor signaling pathways. Front Immunol. 2014;5:461.

29. Wong CK, Cheung PFY, IpWK, Lam CWK. Intracellular signaling mechanisms regulating toll-like receptor-mediated activation of eosinophils. Am J Respir Cell Mol Biol. 2007;37:85-96.

30. Nagase $H$, Okugawa $S$, Ota $Y$, Yamaguchi $M$, Tomizawa $H$,

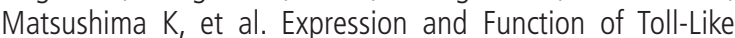
Receptors in Eosinophils: Activation by Toll-Like Receptor 7 Ligand. J Immunol. 2003;171:3977-82.

31. Diebold SS, Kaisho T, Hemmi H, Akira S, Reis e Sousa C. Innate antiviral responses by means of TLR7-mediated recognition of single-stranded RNA. Science. 2004;303:1529-31.

32. Mansson A, Cardell L-O. Role of atopic status in Toll-like receptor (TLR)7- and TLR9-mediated activation of human eosinophils. J Leukoc Biol. 2009;85:719-27.

33. Shen ZJ, Hu J, Kashi V, Bochkov YA, Gern JE, Malter JS. TLR7 Stress Signaling in Differentiating and Mature Eosinophils Is Mediated by the Prolyl Isomerase Pin1. J Immunol. 2018:201:3503-13.

34. Perales-Linares $R$, Navas-Martin S. Toll-like receptor 3 in viral pathogenesis: friend or foe? Immunology. 2013;140:153-67.

35. Månsson $A$, Fransson $M$, Adner $M$, Benson $M_{1}$ Uddman $R_{t}$ Björnsson $S$, et al. TLR3 in human eosinophils: functional effects and decreased expression during allergic rhinitis. Int Arch Allergy Immunol. 2010;151:118-28.

36. Kvarnhammar AM, Petterson T, Cardell L-O. NOD-like receptors and RIG-I-like receptors in human eosinophils: activation by NOD1 and NOD2 agonists. Immunology. 2011;134:314-25.

37. Loo YM, Gale M Jr. Immune signaling by RIG-I-like receptors. Immunity. 2011;34:680-92.

38. Herold S, Becker C, Ridge KM, Budinger GRS. Influenza virus-induced lung injury: Pathogenesis and implications for treatment. Eur Respir J. 2015;45:1463-78.

39. Lotfi R, Herzog GI, DeMarco RA, Beer-Stolz D, Lee JJ, Rubartelli A, et al. Eosinophils Oxidize Damage-Associated Molecular
Pattern Molecules Derived from Stressed Cells. J Immunol. 2009;183:5023-31.

40. Padigel UM, Lee JJ, Nolan TJ, Schad GA, Abraham D. Eosinophils can function as antigen-presenting cells to induce primary and secondary immune responses to Strongyloides stercoralis. Infect Immun. 2006;74:3232-8.

41. Wang H-B, Ghiran I, Matthaei K, Weller PF. Airway Eosinophils: Allergic Inflammation Recruited Professional AntigenPresenting Cells. J Immunol. 2007; 179:7585-92.

42. Lucey DR, Nicholson-Weller A, Weller PF. Mature human eosinophils have the capacity to express HLA-DR. Proc Natl Acad Sci U S A. 1989;86:1348-51.

43. Woerly G, Roger N, Loiseau S, Dombrowicz D, Capron A, Capron M. Expression of CD28 and CD86 by human eosinophils and role in the secretion of type 1 cytokines (interleukin 2 and interferon $\gamma$ ): Inhibition by immunoglobulin A complexes. J Exp Med. 1999;190:487-95.

44. Samarasinghe AE, Melo RC, Duan S, LeMessurier KS, Liedmann S, Surman SL, et al. Eosinophils Promote Antiviral Immunity in Mice Infected with Influenza A Virus. J Immunol. 2017:198:3214-26.

45. Handzel ZT, Busse WW, Sedgwick JB, Vrtis R, Lee WM, Kelly EA, et al. Eosinophils bind rhinovirus and activate virus-specific $T$ cells. J Immunol. 1998;160:1279-84.

46. Shi HZ, Humbles A, Gerard C, Jin Z, Weller PF. Lymph node trafficking and antigen presentation by endobronchial eosinophils. J Clin Invest. 2000;105:945-53.

47. Duez C, Dakhama A, Tomkinson A, Marquillies P, Balhorn A, Tonnel $A B$, et al. Migration and accumulation of eosinophils toward regional lymph nodes after airway allergen challenge. J Allergy Clin Immunol. 2004;114:820-5.

48. Celestin J, Rotschke O, Falk K, Ramesh N, Jabara H, Strominger J, et al. IL-3 Induces B7.2 (CD86) Expression and Costimulatory Activity in Human Eosinophils. J Immunol. 2001;167:6097-104.

49. Tamura N, Ishii N, Nakazawa M, Nagoya M, Yoshinari $M$, Amano $T$, et al. Requirement of CD80 and CD86 molecules for antigen presentation by eosinophils. Scand J Immunol. 1996;44:229-38.

50. Mawhorter SD, Kazura JW, Boom WH. Human eosinophils as antigen-presenting cells: relative efficiency for superantigenand antigen-induced CD4+ T-cell proliferation. Immunology. 1994;81:584-591.

51. Rosenberg HF, Domachowske JB. Eosinophils, eosinophil ribonucleases, and their role in host defense against respiratory virus pathogens. J Leukoc Biol. 2001;70:691-8.

52. Rosenberg HF. Eosinophil-Derived Neurotoxin (EDN/RNase 2) and the Mouse Eosinophil-Associated RNases (mEars): Expanding Roles in Promoting Host Defense. Int J Mol Sci. 2015;16:15442-55.

53. Li Y, Zhao Y, Liu J, Huang Y, Liu Z, Xue C. A promising alternative anti-HBV agent: the targeted ribonuclease. Int J Mol Med. 2010:26(1):51-6.

54. Rosenberg HF, Domachowske JB. Eosinophils, ribonucleases and host defense: solving the puzzle. Immunol Res. 1999;20:261-74.

55. Domachowske JB, Dyer KD, Adams AG, Leto TL, Rosenberg HF. Eosinophil cationic protein/RNase 3 is another RNase A-family ribonuclease with direct antiviral activity. Nucleic Acids Res. 1998;26:3358-63. 
56. Domachowske JB, Dyer KD, Bonville CA, Rosenberg HF. Recombinant Human Eosinophil-Derived Neurotoxin/RNase 2 Functions as an Effective Antiviral Agent against Respiratory Syncytial Virus. J Infect Dis. 1998;177:1458-64.

57. Domachowske JB, Bonville CA, Dyer KD, Easton AJ, Rosenberg HF. Pulmonary eosinophilia and production of MIP-1alpha are prominent responses to infection with pneumonia virus of mice. Cell Immunol. 2000;200:98-104.

58. Percopo CM, Dyer KD, Ochkur SI, Luo JL, Fischer ER, Lee JJ, et al. Activated mouse eosinophils protect against lethal respiratory virus infection. Blood. 2014;123:743-52.

59. Del Pozo V, de Arruda-Chaves E, de Andrés B, Cárdaba B, López-Farré A, Gallardo $S$, et al. Eosinophils transcribe and translate messenger RNA for inducible nitric oxide synthase. J Immunol. 1997; 158:859-64.

60. Weiss SJ, Test ST, Eckmann CM, Roos D, Regiani S. Brominating oxidants generated by human eosinophils. Science. 1986:234:200-3.

61. Rimmelzwaan GF, Baars MM, de Lijster $P$, Fouchier RA, Osterhaus AD. Inhibition of influenza virus replication by nitric oxide. J Virol. 1999;73:8880-3.

62. Dyer KD, Percopo CM, Fischer ER, Gabryszewski SJ, Rosenberg HF. Pneumoviruses infect eosinophils and elicit MyD88dependent release of chemoattractant cytokines and interleukin-6. Blood. 2009;114:2649-56.

63. Yousefi S, Gold JA, Andina N, Lee JJ, Kelly AM, Kozlowski E, et al. Catapult-like release of mitochondrial DNA by eosinophils contributes to antibacterial defense. Nat Med. 2008;14:949-53.

64. Silveira JS, Antunes GL, Gassen RB, Breda RV, Stein RT, Pitrez $P M$, et al. Respiratory syncytial virus increases eosinophil extracellular traps in a murine model of asthma. Asia Pac Allergy. 2019;9:e32.

65. Schönrich G, Raftery MJ. Neutrophil Extracellular Traps Go Viral. Front Immunol. 2016;7:366.

66. Spencer LA, Szela CT, Perez SAC, Kirchhoffer CL, Neves JS, Radke $A L$, et al. Human eosinophils constitutively express multiple Th1, Th2, and immunoregulatory cytokines that are secreted rapidly and differentially. J Leukoc Biol. 2008;85:117-23.

67. Biron CA. Cytokines in the generation of immune responses to, and resolution of, virus infection. Curr Opin Immunol. 1994;6:530-8.

68. Katze MG, He Y, Gale M Jr. Viruses and interferon: a fight for supremacy. Nat Rev Immunol. 2002;2:675-87.

69. Heymann PW, Carper HT, Murphy DD, Platts-Mills TE, Patrie J, McLaughlin AP, et al. Viral infections in relation to age, atopy, and season of admission among children hospitalized for wheezing. J Allergy Clin Immunol. 2004;114:239-47.

70. Calvo C, Pozo F, García-García ML, Sanchez M, LopezValero $M$, Pérez-Breña $P$, et al. Detection of new respiratory viruses in hospitalized infants with bronchiolitis: A three-year prospective study. Acta Paediatr Int J Paediatr. 2010;99:883-7.

71. Simoes EA. Environmental and demographic risk factors for respiratory syncytial virus lower respiratory tract disease. J Pediatr. 2003;143:S118-26.

72. Chuaychoo B, Ngamwongwan S, Kaewnaphan B, Athipanyasilp N, Horthongkham N, Kantakamalakul W, et al. Clinical manifestations and outcomes of respiratory syncytial virus infection in adult hospitalized patients. J Clin Virol. 2019;117:103-8.
73. Falsey AR, Hennessey PA, Formica MA, Cox C, Walsh EE. Respiratory Syncytial Virus Infection in Elderly and High-Risk Adults. N Engl J Med. 2005;352:1749-59.

74. Kristjánsson $S$, Wennergren $D$, Eriksson $B$, Thórarinsdóttir $H$, Wennergren G. U-EPX levels and wheezing in infants and young children with and without RSV bronchiolitis. Respir Med. 2006;100:878-83.

75. Kim CK, Kim SW, Park CS, Kim B, Kang H, Koh YY. Bronchoalveolar lavage cytokine profiles in acute asthma and acute bronchiolitis. J Allergy Clin Immunol. 2003;112:64-71.

76. Olszewska-Pazdrak B, Pazdrak K, Ogra PL, Garofalo RP. Respiratory syncytial virus-infected pulmonary epithelial cells induce eosinophil degranulation by a CD18-mediated mechanism. J Immunol. 1998;160:4889-95.

77. Levitz R, Gao Y, Dozmorov I, Song R, Wakeland EK, Kahn JS. Distinct patterns of innate immune activation by clinical isolates of respiratory syncytial virus. PLoS One. 2017;12:e0184318.

78. Su Y-C, Townsend D, Herrero LJ, Zaid A, Rolph MS, Gahan $M E$, et al. Dual Proinflammatory and Antiviral Properties of Pulmonary Eosinophils in Respiratory Syncytial Virus VaccineEnhanced Disease. J Virol. 2015;89:1564-78.

79. Kim HW, Canchola JG, Brandt CD, Pyles G, Chanock RM, Jensen $K$, et al. Respiratory syncytial virus disease in infants despite prior administration of antigenic inactivated vaccine. Am J Epidemiol. 1969;89:422-34.

80. Byrd LG, Prince GA. Animal Models of Respiratory Syncytial Virus Infection. Clin Infect Dis. 1997;25:1363-8.

81. Antonis AFG, Schrijver RS, Daus F, Steverink PJGM, Stockhofe $\mathrm{N}$, Hensen EJ, et al. Vaccine-Induced Immunopathology during Bovine Respiratory Syncytial Virus Infection: Exploring the Parameters of Pathogenesis. J Virol. 2003;77:12067-73.

82. Percopo CM, Qiu Z, Phipps S, Foster PS, Domachowske JB, Rosenberg HF. Pulmonary Eosinophils and Their Role in Immunopathologic Responses to Formalin-Inactivated Pneumonia Virus of Mice. J Immunol. 2009;183:604-12.

83. Kapikian AZ, Mitchell RH, Chanock RM, Shvedoff RA, Stewart CE. An epidemiologic study of altered clinical reactivity to respiratory syncytial (RS) virus infection in children previously vaccinated with an inactivated RS virus vaccine. Am J Epidemiol. 1969;89:405-21.

84. Connors M, Kulkarni AB, Firestone $C Y$, Holmes KL, Morse 3rd $H C$, Sotnikov AV, et al. Pulmonary histopathology induced by respiratory syncytial virus (RSV) challenge of formalininactivated RSV-immunized BALB/C mice is abrogated by depletion of CD4+ T cells. J Virol. 1992;66:7444-51.

85. Neuzil KM, Johnson JE, Tang YW, Prieels JP, Slaoui M, Gar N, et al. Adjuvants influence the quantitative and qualitative immune response in BALB/c mice immunized with respiratory syncytial virus FG subunit vaccine. Vaccine. 1997;15:525-32.

86. Castilow EM, Meyerholz DK, Varga SM. IL-13 Is Required for Eosinophil Entry into the Lung during Respiratory Syncytial Virus Vaccine-Enhanced Disease. J Immunol. 2008;180:237684.

87. Johnson TR, Graham BS. Secreted Respiratory Syncytial Virus G Glycoprotein Induces Interleukin-5 (IL-5), IL-13, and Eosinophilia by an IL-4-Independent Mechanism. J Virol. 1999;73:8485-95.

88. Hwang HS, Lee YT, Kim KH, Park S, Kwon YM, Lee Y, et al. Combined virus-like particle and fusion protein-encoding 
DNA vaccination of cotton rats induces protection against respiratory syncytial virus without causing vaccine-enhanced disease. Virology. 2016;494:215-24.

89. Lee Y, Lee Y-T, Ko E-J, Kim K-H, Hwang HS, Park S, et al. Soluble $\mathrm{F}$ proteins exacerbate pulmonary histopathology after vaccination upon respiratory syncytial virus challenge but not when presented on virus-like particles. Hum Vaccin Immunother. 2017;13:2594-605.

90. Lee YT, Kim KH, Hwang HS, Lee Y, Kwon YM, Ko EJ, et al. Innate and adaptive cellular phenotypes contributing to pulmonary disease in mice after respiratory syncytial virus immunization and infection. Virology. 2015;485:36-46.

91. Lee YT, Ko EJ, Kim KH, Hwang HS, Lee Y, Kwon YM, et al. Cellular immune correlates preventing disease against respiratory syncytial virus by vaccination with virus-like nanoparticles carrying fusion proteins. J Biomed Nanotechnol. 2017;13:84-98.

92. Stevens WW, Sun J, Castillo JP, Braciale TJ. Pulmonary Eosinophilia Is Attenuated by Early Responding CD8 + Memory T Cells in a Murine Model of RSV Vaccine-Enhanced Disease. Viral Immunol. 2009;22:243-51.

93. Olson MR, Hartwig SM, Varga SM. The Number of Respiratory Syncytial Virus (RSV)-Specific Memory CD8 T Cells in the Lung Is Critical for Their Ability to Inhibit RSV Vaccine-Enhanced Pulmonary Eosinophilia. J Immunol. 2008;181:7958-68.

94. Pennings JL, Schuurhof A, Hodemaekers HM, Buisman A, de Rond LC, Widjojoatmodjo MN et al. Systemic signature of the lung response to respiratory syncytial virus infection. PLoS One. 2011;6:e21461.

95. Castilow EM, Legge KL, Varga SM. Cutting Edge: Eosinophils Do Not Contribute to Respiratory Syncytial Virus VaccineEnhanced Disease. J Immunol. 2008;181:6692-6.

96. Knudson CJ, Hartwig SM, Meyerholz DK, Varga SM. RSV Vaccine-Enhanced Disease Is Orchestrated by the Combined Actions of Distinct CD4 T Cell Subsets. PLOS Pathog. 2015;11:e1004757.

97. Prince GA, Curtis SJ, Yim KC, Porter DD. Vaccine-enhanced respiratory syncytial virus disease in cotton rats following immunization with Lot 100 or a newly prepared reference vaccine. J Gen Virol. 2001;82:2881-8.

98. Rosenberg HF, Dyer KD, Domachowske JB. Respiratory viruses and eosinophils: exploring the connections. Antiviral Res. 2009;83:1-9.

99. Flores-Torres AS, Salinas-Carmona MC, Salinas E, RosasTaraco AG. Eosinophils and Respiratory Viruses. Viral Immunol. 2019;32:198-207.

100. Jacobs SE, Lamson DM, Kirsten S, Walsh TJ. Human rhinoviruses. Clin Microbiol Rev. 2013;26:135-62.

101. Song DJ. Rhinovirus and childhood asthma: An update. Korean J Pediatr. 2016;59:432-9.

102. Sabogal Piñeros YS, Bal SM, Dijkhuis A, Majoor CJ, Dierdorp BS, Dekker T, et al. Eosinophils capture viruses, a capacity that is defective in asthma. Allergy. 2019;74:1898-909.

103. Sabogal Piñeros YS, Bal SM, van de Pol MA, Dierdorp BS, Dekker T, Dijkhuis A, et al. Anti-IL-5 in Mild Asthma Alters Rhinovirus-induced Macrophage, B-Cell, and Neutrophil Responses (MATERIAL) A Placebo-controlled, Double-Blind Study. Am J Respir Crit Care Med. 2019;199(4):508-17.

104. Petrova VN, Russell CA. The evolution of seasonal influenza viruses. Nat Rev Microbiol. 2018;16:60.
105. Taubenberger JK, Kash JC. Influenza virus evolution, host adaptation, and pandemic formation. Cell Host Microbe. 2010;7:440-51.

106. Influenza (Seasonal). Available from: https://www.who.int/ news-room/fact-sheets/detail/influenza-(seasonal)

107. Bramley AM, Dasgupta S, Skarbinski J, Kamimoto L, Fry $A M$, Finelli $L$, et al. Intensive care unit patients with 2009 pandemic influenza A (H1N1pdm09) virus infection - United States, 2009. Influenza Other Respir Viruses. 2012;6:e134-42.

108. Vaillant L, La Ruche G, Tarantola A, Barboza P, for the epidemic intelligence team. Epidemiology of fatal cases associated with pandemic H1N1 influenza 2009. Eurosurveillance. 2009;14:19309

109. Samarasinghe AE, Woolard SN, Boyd KL, Hoselton SA, Schuh JM, McCullers JA. The immune profile associated with acute allergic asthma accelerates clearance of influenza virus. Immunol Cell Biol [Internet]. 2014;92:449-59.

110. Ishikawa H, Sasaki H, Fukui T, Fujita K, Kutsukake E, Matsumoto T. Mice with asthma are more resistant to influenza virus infection and NK cells activated by the induction of asthma have potentially protective effects. I Clin Immunol. 2012;32:256-67.

111. Terai $M$, Honda $T$, Yamamoto $S$, Yoshida $M$, Tsuchiya $N$ Moriyama $Y$, et al. Early induction of interleukin-5 and peripheral eosinophilia in acute pneumonia in Japanese children infected by pandemic 2009 influenza A in the Tokyo area. Microbiol Immunol. 2011;55(5):341-6.

112. Gorski SA, Hahn YS, Braciale TJ. Group 2 Innate Lymphoid Cell Production of IL-5 Is Regulated by NKT Cells during Influenza Virus Infection. Wherry EJ, editor. PLoS Pathog. 2013:9:e1003615.

113. DiPiazza A, Nogales A, Poulton N, Wilson PC, Martínez-Sobrido L, Sant AJ. Pandemic 2009 H1N1 Influenza Venus reporter virus reveals broad diversity of MHC class II-positive antigenbearing cells following infection in vivo. Sci Rep. 2017;7:1-17.

114. Papadopoulos NG, Christodoulou I, Rohde G, Agache I, Almqvist C, Bruno A et al. Viruses and bacteria in acute asthma exacerbations--a GA2LEN-DARE systematic review. Allergy. 2011;66:458-68.

115. Adamko DJ, Yost BL, Gleich GJ, Fryer AD, Jacoby DB. Ovalbumin sensitization changes the inflammatory response to subsequent parainfluenza infection: Eosinophils mediate airway hyperresponsiveness, M2 muscarinic receptor dysfunction, and antiviral effects. J Exp Med. 1999;190:146577.

116. Drake MG, Bivins-Smith ER, Proskocil BJ, Nie Z, Scott GD, Lee JJ, et al. Human and mouse eosinophils have antiviral activity against parainfluenza virus. Am J Respir Cell Mol Biol. 2016:55:387-94.

117. Ottolini MG, Porter DD, Hemming VG, Prince GA. Enhanced pulmonary pathology in cotton rats upon challenge after immunization with inactivated parainfluenza virus 3 vaccines. Viral Immunol. 2000;13:231-6.

118. Jiang S, Bottazzi ME, Du L, Lustigman S, Tseng C-TK, Curti $E$, et al. Roadmap to developing a recombinant coronavirus $S$ protein receptor-binding domain vaccine for severe acute respiratory syndrome. Expert Rev Vaccines. 2012;11:1405-13.

119. Lindsley AW, Schwartz JT, Rothenberg ME. Eosinophil responses during COVID-19 infections and coronavirus 
vaccination [published online ahead of print, $2020 \mathrm{Apr} 25$ ]. J Allergy Clin Immunol. 2020;S0091-6749(20)30569-8.

120. Castilow EM, Olson MR, Varga SM. Understanding respiratory syncytial virus (RSV) vaccine-enhanced disease. Immunol Res. 2007;39:225-39.

121. Collins PL, Graham BS. Viral and Host Factors in Human Respiratory Syncytial Virus Pathogenesis. J Virol. 2008 Mar 1;82:2040-55.

122. Deming $D$, Sheahan $T$, Heise $M$, Yount $B$, Davis $N$, Sims $A$, et al. Vaccine Efficacy in Senescent Mice Challenged with Recombinant SARS-CoV Bearing Epidemic and Zoonotic Spike Variants. PLoS Med. 2006;3:e525.

123. Bolles M, Deming D, Long K, Agnihothram S, Whitmore A, Ferris $M$, et al. A Double-Inactivated Severe Acute Respiratory Syndrome Coronavirus Vaccine Provides Incomplete Protection in Mice and Induces Increased Eosinophilic Proinflammatory Pulmonary Response upon Challenge. J Virol. 2011;85:1220115.

124. Yasui F, Kai C, Kitabatake M, Inoue S, Yoneda M, Yokochi $S$, et al. Prior Immunization with Severe Acute Respiratory Syndrome (SARS)-Associated Coronavirus (SARS-CoV) Nucleocapsid Protein Causes Severe Pneumonia in Mice Infected with SARS-CoV. J Immunol. 2008;181:6337-48.

125. Du L, Zhao G, He Y, Guo Y, Zheng BJ, Jiang S, et al. Receptorbinding domain of SARS-CoV spike protein induces longterm protective immunity in an animal model. Vaccine. 2007:25:2832-8.

126. Tseng C-T, Sbrana E, Iwata-Yoshikawa N, Newman PC, Garron $\mathrm{T}$, Atmar RL, et al. Immunization with SARS Coronavirus Vaccines Leads to Pulmonary Immunopathology on Challenge with the SARS Virus. PLoS One. 2012;7:e35421.

127. Spruth M, Kistner O, Savidis-Dacho H, Hitter E, Crowe B, Gerencer $\mathrm{M}$, et al. A double-inactivated whole virus candidate SARS coronavirus vaccine stimulates neutralising and protective antibody responses. Vaccine. 2006;24:652-61.

128. Kusters IC, Matthews J, Saluzzo JF. Manufacturing Vaccines for an Emerging Viral Infection-Specific Issues Associated with the Development of a Prototype SARS Vaccine. Vaccines for Biodefense and Emerging and Neglected Diseases. 2009;30:147-56.

129. Zhou Z, Post P, Chubet R, Holtz K, McPherson C, Petric M, et al. A recombinant baculovirus-expressed $S$ glycoprotein vaccine elicits high titers of SARS-associated coronavirus (SARS-CoV) neutralizing antibodies in mice. Vaccine. 2006;24:3624-31.

130. Lokugamage KG, Yoshikawa-Iwata N, Ito N, Watts DM, Wyde PR, Wang N, et al. Chimeric coronavirus-like particles carrying severe acute respiratory syndrome coronavirus (SCoV) S protein protect mice against challenge with SCoV. Vaccine. 2008:26:797-808.

131. Honda-Okubo Y, Barnard D, Ong CH, Peng B-H, Tseng C-TK, Petrovsky N. Severe Acute Respiratory Syndrome-Associated Coronavirus Vaccines Formulated with Delta Inulin Adjuvants Provide Enhanced Protection while Ameliorating Lung Eosinophilic Immunopathology. J Virol. 2015;89:2995-3007.

132. Iwata-Yoshikawa N, Uda A, Suzuki T, Tsunetsugu-Yokota Y, Sato Y, Morikawa S, et al. Effects of Toll-Like Receptor Stimulation on Eosinophilic Infiltration in Lungs of BALB/c Mice Immunized with UV-Inactivated Severe Acute Respiratory SyndromeRelated Coronavirus Vaccine. J Virol. 2014;88:8597-614.
133. WHO Coronavirus (COVID-19) Dashboard |WHO Coronavirus Disease (COVID-19) Dashboard. Available from: https:// covid19.who.int/

134. Du Y, Tu L, Zhu P, Mu M, Wang R, Yang $P$, et al. Clinical Features of 85 Fatal Cases of COVID-19 from Wuhan: A Retrospective Observational Study. Am J Respir Crit Care Med. 2020;201:1372-9.

135. Zhang JJ, Dong X, Cao YY, Yuan Y-D, Yang Y-B, Yan Y-Q, et al. Clinical characteristics of 140 patients infected with SARSCoV-2 in Wuhan, China. Allergy. 2020;10.1111/all.14238.

136. Wang Z, Yang B, Li Q, Wen L, Zhang R. Clinical Features of 69 Cases with Coronavirus Disease 2019 in Wuhan, China. Clin Infect Dis. 2020;ciaa272. doi:10.1093/cid/ciaa272

137. Qin C, Zhou L, Hu Z, Zhang S, Yang S, Tao Y, et al. Dysregulation of Immune Response in Patients With Coronavirus 2019 (COVID-19) inWuhan, China Clin Infect Dis. 2020 Mar;ciaa248.

138. Yun H, Sun Z, Wu J, Tang A, Hu M, Xiang Z. Laboratory data analysis of novel coronavirus (COVID-19) screening in 2510 patients. Clin Chim Acta. 2020;507:94-7.

139. Qian GQ, Yang NB, Ding F, Ma AHY, Wang Z-Y, Shen Y-F, et al. Epidemiologic and Clinical Characteristics of 91 Hospitalized Patients with COVID-19 in Zhejiang, China: A retrospective, multi-centre case series. QJM. 2020 Mar 17;hcaa089.

140. Hotez PJ, Bottazzi ME, Corry DB. The potential role of Th17 immune responses in coronavirus immunopathology and vaccine-induced immune enhancement Microbes Infect. 2020;S1286-4579(20)30072-1.

141. Conti P, Ronconi G, Caraffa A, Gallenga C, Ross R, Frydas I, et al. Induction of pro-inflammatory cytokines (IL-1 and IL-6) and lung inflammation by Coronavirus-19 (COVI-19 or SARSCoV-2): anti-inflammatory strategies. J Biol Regul Homeost Agents. 2020;34:1.

142. Liu L, Wei Q, Lin Q, Fang J, Wang H, Kwok H, et al. Anti-spike IgG causes severe acute lung injury by skewing macrophage responses during acute SARS-COV infection. JCI Insight. 2019;4:e123158.

143. Liao M, Liu Y, Yuan J, Wen $Y, X u$ G, Zhao J, et al. Single-cell landscape of bronchoalveolar immune cells in patients with COVID-19. Nat Med. 2020 May 12.

144. Akdis CA, Arkwright PD, Brüggen MC, Busse W, Gadina M, Guttman-Yassky $E$, et al. Type 2 immunity in the skin and lungs. Allergy. 2020;10.1111/all.14318.

145. Sastre B, Rodrigo-Muñoz JM, Garcia-Sanchez DA, Cañas JA, Del Pozo V. Eosinophils: Old Players in a New Game. J Investig Allergol Clin Immunol. 2018;28:289-304.

146. Holland M, Alkhalil M, Chandromouli S, Janjua A, Babores M. Eosinopenia as a marker of mortality and length of stay in patients admitted with exacerbations of chronic obstructive pulmonary disease. Respirology. 2010;15:165-7.

147. Steer J, Gibson J, Bourke SC. The DECAF score: Predicting hospital mortality in exacerbations of chronic obstructive pulmonary disease. Thorax. 2012;67:970-6.

148. Lavoignet CE, Le Borgne $P$, Chabrier S, Bidoire J, Slimani $\mathrm{H}$, Chevrolet-Lavoignet J, et al. White blood cell count and eosinopenia as valuable tools for the diagnosis of bacterial infections in the ED. Eur J Clin Microbiol Infect Dis. 2019:38:1523-32.

149. Bass DA, Gonwa TA, Szejda P, Cousart MS, DeChatelet LR, McCall CE. Eosinopenia of acute infection. Production of 
eosinopenia by chemotactic factors of acute inflammation. J Clin Invest. 1980;65:1265-71.

150. Lippi G, Henry BM. Eosinophil count in severe coronavirus disease 2019 (COVID-19). QJM. 2020;hcaa137. doi:10.1093/ qjmed/hcaa137.

151. Sun $Y$, Dong $Y$, Wang L, Xie H, Li B, Chang $C$ et al. Characteristics and prognostic factors of disease severity in patients with COVID-19: The Beijing experience. J Autoimmun. 2020; 102473.

152. Liu F, Xu A, Zhang Y, Xuan W, Yan T, Pan K, et al. Patients of COVID-19 may benefit from sustained Lopinavir-combined regimen and the increase of Eosinophil may predict the outcome of COVID-19 progression. Int J Infect Dis. 2020;95:183-91.

153. Liu S, Zhi Y, Ying S. COVID-19 and Asthma: Reflection During the Pandemic. Clin Rev Allergy Immunol. 2020;10.1007/ s12016-020-08797-3.

154. Matucci A, Maggi E, Vultaggio A. Eosinophils, the IL-5/IL$5 R \alpha$ axis, and the biologic effects of benralizumab in severe asthma. Respir Med. 2019;160:105819.
155. Wardlaw AL. Molecular basis for selective eosinophil trafficking in asthma: A multistep paradigm. J Allergy Clin Immunol. 1999;104:917-26.

156. Jesenak M, Banovcin P, Diamant Z. COVID-19, chronic inflammatory respiratory diseases and eosinophils Observations from reported clinical case series. Allergy. 2020;10.1111/all.14353. Manuscript received June 9, 2020; accepted for
publication June 15, 2020 .

\section{Victoria del Pozo, PhD}

Immunology Dept.

IIS-Fundación Jiménez Díaz

Av. Reyes Católicos 2

28040 Madrid, Spain 